\title{
NAIL-FOLD EXCISION WITHOUT MATRICECTOMY FOR TREATMENT OF INGROWN TOE NAILS
}

\author{
By \\ Mohammad Arafat Abdel-Maksoud \\ General Surgery Department, Faculty of Medicine, Al-Azhar University
}

\begin{abstract}
Background: Ingrown toe nails are a painful condition occurs when one of the distal sides of nail plates causes pressure or actually punctures the periungual skin. A wide variety of treatment modalities are existed in the literature.
\end{abstract}

Objectives: Evaluation of the technique of lateral nail-fold excision without matricectomy in treatment of ingrown toenails.

Patients and Methods: The study was a prospective observational study carried on 83 patients; 57 males

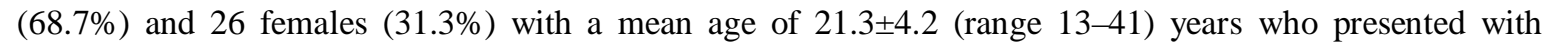
ingrown toe nails. All patients underwent lateral nail fold excision technique as a treatment of ingrown toe nails.

Results: Recurrence rate was $3.6 \%$, postoperative erythema and swelling was $3.6 \%$, and inflammatory exudate was $4.8 \%$. Significant loss of sensation around the area of surgery was $2.4 \%$, and $94 \%$ of patients were strongly satisfied with the procedure.

Conclusion: This technique was effective in treatment of ingrown toe nails with a low rate of recurrence, less pain, good cosmetic results, and high satisfaction rates.

Key words: Ingrown toe nails, nail fold, nail matrix.

\section{INTRODUCTION}

Ingrown toe nails (onychocryptosis) are a painful condition occurring when one of the distal sides of nail plates cause pressure or actually punctures the periungual skin. It causes irritation of the underlying skin and leads to inflammation, pain, formation of granulation tissue and, in some cases, infection (Heidelbaugh and Lee, 2009). It commonly affects the lateral edge of the big toe, although the medial edge and other toes can also be affected. Ingrown toe nails mostly occur in males aged 1540 years (Park and Singh, 2012).

A number of causes have been suggested, including wearing constricting footwear, improper trimming of the nail or tearing nails off (Yang et al., 2008).

Risk factors that may increase the incidence of ingrowing toe nails are diabetes and obesity, as well as renal, cardiac, and thyroid disorders that may predispose people to lower limb edema. Also, hyperhidrosis and poor foot hygiene, onychomycosis (fungal nail 
infection) and family history of ingrown toe nails are included (Richert, 2012).

A wide variety of treatment modalities are included in the literature. However, it is associated with unacceptable cosmetic results, high rates of recurrence and low rates of patient satisfaction (Kruijff et al., 2008 and Haneke, 2012).

Initial treatment of an ingrown toe nail is conservative which includes avoiding tight-fitting shoes, using warm water soaks, proper nail trimming and elevation of the nail corner, and topical and oral antibiotic therapy (Watabe et al., 2015).

Surgical intervention is ultimately required in refractory cases. A 2012 Cochrane review reported that surgical treatment is more effective in lowering recurrence of an ingrown toe nail than non-surgical management (Haneke, 2012).

Most surgical procedures are variations of two different approaches which either target the nail plate or the lateral skin folds that surround the toenail. Surgical treatments have previously focused on the nail as the causative agent, and the most commonly performed procedure is the "wedge resection" technique that involves partial removal of the toenail. Evidence suggests that a surgical approach that targets the nail folds and leaves the toe nail intact should be considered more often, as low recurrence rates have been observed (Chapeskie and Kovac, 2010).

The present study was done to evaluate the technique of lateral nail-fold excision only without matricectomy in treatment of ingrown toe nails.

\section{PATIENTS AND METHODS}

This study was a prospective, observational study performed at the Department of Surgery, Al-Azhar University Hospitals during the period between January 2017 and March 2018. It was carried out on 83 patients; 57 males $(68.7 \%)$ and 26 females $(31.3 \%)$ with a mean age of $21.3 \pm 4.2$ (range 13-41) years who presented with ingrown toe nails. Fifteen (18\%) patients presented with stage 1 ingrown toe nails (erythema, tenderness, and swelling of nail fold); stage 2 ingrown toe nail (seropurulant drainage and infection) in 40 (48.2\%) patients; and the last $28(33.8 \%)$ patients were affected with stage 3 ingrown toe nail (granulation tissue and marked nail fold hypertrophy). Patients with infection were operated after 1 week of oral antibiotic treatment. Of the patients studied, 18 patients $(21.6 \%)$ had previous failed attempts to surgically correct their ingrown toe nails by other surgeons. All patients were allowed for lateral soft tissue nail fold excision technique as a treatment of ingrown toe nails.

The study was approved by the Local Ethics Committee of Surgery Department. All patients were interviewed and inquired about the history as regards symptoms, onset, course, duration, and previous treatment, good physical examination was performed before surgical interference. All patients signed a detailed informed consent.

Surgical technique: The involved toe was sterilized with bovidine iodine, and ring nerve block anesthesia was applied with $2 \%$ lidocaine without epinephrine. Tourniquet was placed at the base of the toe to maintain bloodless surgical field 
and to help local anesthetic penetration into the tissue. An incision of $5 \mathrm{~mm}$ was made proximally from the base of the nail, at the proximal nail fold. Care was taken to leave the nail matrix intact. An elliptical extension was made out to the side and bottom of the toe, extending distally to involve all granulation tissue and nail-fold skin. The incision was continued to end up under the tip of the nail and all skin and subcutaneous tissues at the edge of the nail were removed. The excision was generous and adequate, and occasionally exposing a portion of the distal phalanx. Application of electrocautery was used to reduce postoperative bleeding. The wound was allowed to close by secondary intention. A piece of gauze was folded and applied over the site of the excision followed by 2 gauze pads and then rolled gauze $(5-\mathrm{cm}$ width). Dressing every 48 hours occurred until healing was completed. Pain control was achieved with non-steroidal antiinflammatory drugs. There was no need for antibiotics.

Post-operative follow-up: Wound healing, recurrence and patient satisfaction were noted. The follow up period was weekly until wound healing was completed, then monthly for one year. Patients lost during follow up period were excluded from this analysis.

Statistical analysis: Data were summarized by mean \pm standard deviation and categorical variables were expressed as percentage $(\%)$.
In our study, 83 patients underwent surgical management of ingrown toe nails in the form of lateral soft tissue nail fold excision without matricectomy. Their characteristics were recorded in table (1). They were evaluated during the follow-up period (one year). The mean time of complete healing was $16.4 \pm 6.7$ days. As regard postoperative problems; only 3 patients (3.6\%) had recurrence, 3 patients showed erythema and swelling (3.6\%), 4 patients showed inflammatory exudates $(4.8 \%)$ and 2 patients showed inflammatory granulation (2.4\%). Additionally, loss of cutaneous sensation around the operative site was absent in 75 patients (90\%). However, there was significant loss of sensation around the area of surgery in 2 patients (2.4\%), minimal loss of sensation in 6 patients (7.2\%). 78 patients (94\%) were strongly satisfied with the procedure, and none of the patients were highly dissatisfied with the surgery. The failure rate was $3.6 \%$ with this method and successful surgical treatment was $96.4 \%$ (Table 2). 
Table (1): Patient's characteristics

\begin{tabular}{|l|c|}
\hline \multicolumn{1}{|c|}{ Characters } & Values \\
\hline Patient's No & 83 \\
\hline Sex: & $57(68.7 \%)$ \\
Male & $26(31.3 \%)$ \\
Female & $21.3 \pm 4.2($ range $13-41)$ \\
\hline Age (years) (Mean + SD) & $15(18.1 \%)$ \\
\hline Stages of ingrown toenails: & $40(48.2 \%)$ \\
Stage 1 & $28(33.7 \%)$ \\
Stage 2 & $18(21.7 \%)$ \\
Stage 3 & \\
\hline Recurrent cases & \\
\hline
\end{tabular}

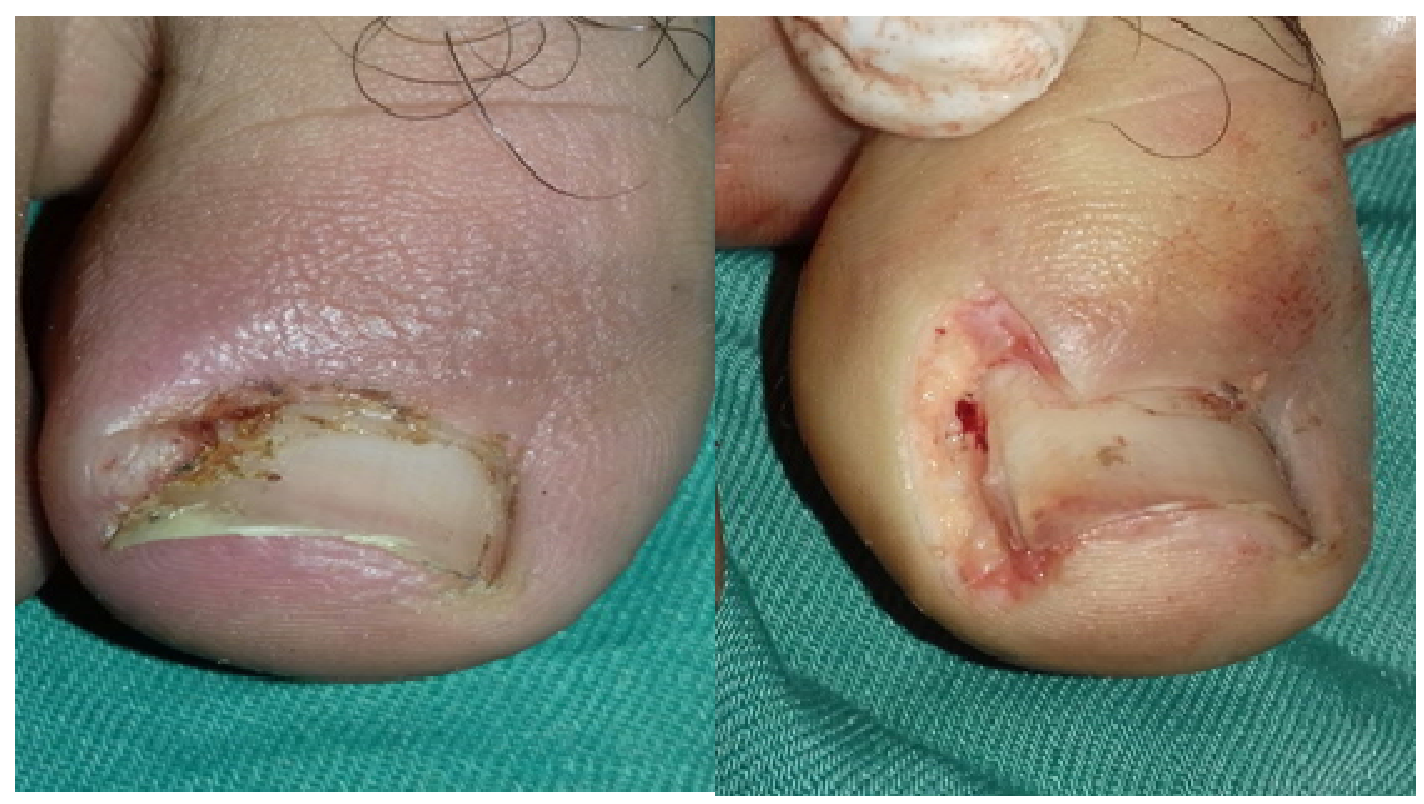

Figure (1): Ingrown toe nails

Figure (2): Lateral nail fold excision

Table (2): Postoperative parameters

\begin{tabular}{|l|c|}
\hline \multicolumn{1}{|c|}{ Parameters } & Value \\
\hline Time of healing (days) & $16.4 \pm 6.7$ \\
\hline Recurrence & $3(3.6 \%)$ \\
\hline Erythema and swelling & $3(3.6 \%)$ \\
\hline Inflammatory exudates & $4(4.8 \%)$ \\
\hline Inflammatory granulation & $2(2.4 \%)$ \\
\hline Significant sensory loss & $2(2.4 \%)$ \\
Minimal sensory loss & $6(7.2 \%)$ \\
\hline Patient's satisfaction & $78(94 \%)$ \\
\hline Rate of success & $80(96.4 \%)$ \\
\hline
\end{tabular}




\section{DISCUSSION}

Ingrown toe nail is a small but important problem. It has controversies both in the pathogenesis and treatment. The etiology of ingrown toe nail may be related to nail plate hence the name ingrown toe nails or hypertrophic lateral soft tissue nail fold covering the nail so like to call it onychocryptosis (Kim et al., 2014).

Different techniques have been used for management. Conservative treatment is reasonable in patients with a mild to moderate degree ingrown toe nails who do not have significant pain. In severe cases or failed conservative treatment, surgical therapy is recommended. Surgical maneuvers include partial nail avulsion or complete nail excision with or without partial matricectomy. However, the recurrence rate has been a considerable problem (Aksoy et al., 2009, Vaccari et al., 2010, and Al Ghamdi \& Khurram, 2014).

The "Winograd operation" is a classical surgical procedure for ingrown toe nails, is to remove one-quarter of the nail bed. Although there is a satisfactory cure rate, it gives poor cosmetic results due to the too-narrow nail plate (Tassara et al., 2011), especially when both sides of the toe are affected.

A study done by (Misiak et al., 2014) on 60 patients with ingrowing toe nail were randomized into two groups, group (1) underwent partial matrixectomy and electrocautary, and group (2) underwent partial matrixectomy and phenol application. They had thirteen recurrences during the follow up period, five (16.6\%) in the phenolization group and eight
$(26.6 \%)$ in the electrocautary group. Also, a trial by (Kruijff et al., 2008) noted an improved but still unsatisfactory 1-year recurrence rate of $6.9 \%$ for partial nail avulsion and surgical matricectomy.

In our study, we excised the lateral fold and inflammatory granulation tissue only without removal of nail or nail matrix. Recurrence rate was $3.6 \%$, postoperative erythema and swelling was $3.6 \%$, inflammatory exudate was $4.8 \%$ and inflammatory granulation was $2.4 \%$. Significant loss of sensation around the area of surgery was $2.4 \% .94 \%$ of patients were strongly satisfied with the procedure, and none of the patients were highly dissatisfied with the surgery.

(Chapeskie and Kovac, 2010) in their case series on 124 patients; the surgical approach involved was the excision of excessive nail-fold granulation tissue with preservation of the nail and its matrix. $72.5 \%$ of patients were under the age of 29 (69.4\% men). A median follow-up of 8 years; no recurrences were identified in any patients $(0 \%)$. Overall, $94.3 \%$ stated that they were highly satisfied with the procedure. Only $1.6 \%$ reported a loss of sensation at the surgical site.

Another study prepared by (Noel, 2008) on twenty-three patients with ingrown toe nail, the patients underwent excision of a large volume of soft tissue surrounding the nail plate without matricectomy under local anesthesia. Short-term results were excellent. No recurrences or severe complications were observed during the minimum 12-months follow-up period. Cosmetic results were remarkable. 


\section{CONCLUSION}

The surgical technique that involves the excision of lateral nail fold only without affection of nail or nail matrix is effective in treatment of ingrown toenails with a low rate of recurrence, less pain, good cosmetic results and high satisfaction rates.

\section{REFERENCES}

1. Aksoy B, Aksoy HM, Civas E, Oc B and Atakan N (2009): Lateral fold-plasty with or without partial matricectomy for the management of ingrown toe nails. Dermatol Surg., 35: 462-468.

2. Al Ghamdi KM and Khurram H (2014): Nail tube splinting method versus lateral nail avulsion with phenol matricectomy: a prospective randomized comparative clinical trial for ingrown toenail treatment. Dermatol Surg., 40(11):1214-20.

3. Chapeskie H and Kovac JR (2010): Case Series: Soft-tissue nail-fold excision: a definitive treatment for ingrown toenails. Can J Surg., 53: 282-6.

4. Haneke $\mathbf{E}$ (2012): Controversies in the treatment of ingrown nails. Dermatol Res Pract., 783924: 1-12.

5. Heidelbaugh JJ and Lee $H$ (2009): Management of the ingrown toe nail. Am Fam Physician, 15(79): 303-8.

6. Kim M, Song IG and Kim HJ (2014): Partial removal of nail matrix in the treatment of ingrown nails: prospective randomized control study between curettage and electrocauterization. Int J Low Extrem Wounds, 25:192-5.

7. Kruijff S, van Det RJ, van der Meer GT, van den Berg IC, van der Palen $J$ and Geelkerken RH (2008): Partial matrix excision or orthonyxia for ingrowing toe nails. J Am Coll Surg., 206:148-53.
8. Misiak P, Terlecki A, Rzepkowska-Misiak B, Weisto S and Brocki M (2014): Comparison of effectiveness of electrocautery and phenol application in partial matricectomy after partial nail extraction in the treatment of ingrown nails. Pol Przegl Chir., 86(2):89-93.

9. Noel B (2008): Surgical treatment of ingrowing toe nail without matricectomy. Dermatol Surg., 34:79-83.

10. Park DH and Singh D (2012): The management of ingrowing toenails. BMJ., 344: $37-40$.

11. Richert B (2012): Surgical management of ingrown toe nails; an update overdue. Dermatol Ther., 25: 498-509.

12. Tassara G, Machado MA and Gouthier MA (2011): Treatment of ingrown nail: comparison of recurrence rates between the nail matrix phenolization classical technique and phenolization associated with nail matrix curettage - is the association necessary? A Bras Dermatol., 86(5):1046-8.

13. Vaccari S, Dika E, Balestri R, Rech G, Piraccini BM and Fanti PA (2010): Partial excision of matrix and phenolic ablation for the treatment of ingrowing toenail: a 36-month follow-up of 197 treated patients. Dermatol Surg., 6(8):1288-93.

14. Watabe A, Yamasaki K, Hashimoto $A$ and Aiba S (2015): Retrospective evaluation of conservative treatment for 140 ingrown toe nails with a novel taping procedure. Acta Derm Venereol., 95(7): 822-5.

15. Yang G, Yanchar NL, Lo AY and Jones SA (2008): Treament of ingrown toe nails in the pediatric population. J Pediatr Surg., 43: 931-5. 


\section{NAIL-FOLD EXCISION WITHOUT MATRICECTOMY FOR TREATMENT... 327}

\section{إستئصال ثتبة الظفر بدون إستئصسال جذره فى علاج الظفر الغائر}

\section{محمد عرفات عبد المقصود}

\section{قسم الجراحة العامةـ كلية الطبـ جامعة الأزهر}

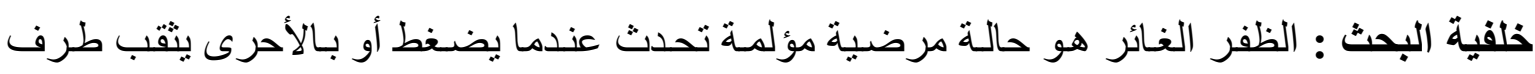
الظفر الأنسجة الجانبية له. و هناك طرق متعددة لعلاج الظفر الغائر.

الهـف من البحث: تقييم طريقة إستئصال ثنية الظفر بدون إستئصال جذره فى علاج الظفر الغائر.

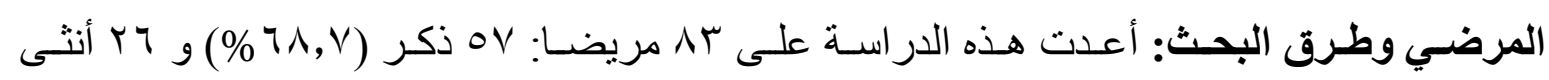

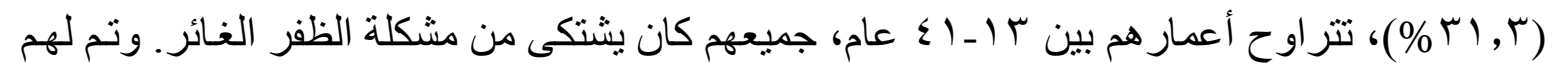

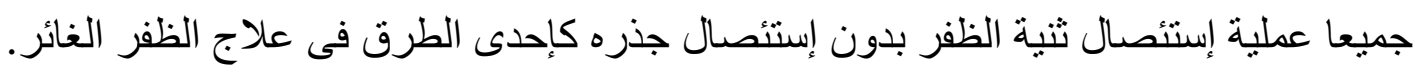

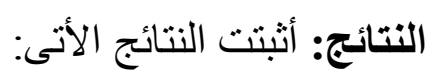
- معدل رجوع المشكلة مرة أخرى كان (؟ بr\%\%). - نسبة حدوث تورم وإحمر ار حول مكان العطلية (†,r\%). ـ نسبة حدوث إفرازات من جرح العملية (^,§؟\%). ـ فقدان الإحساس الجلدى حول مكان العملية (ـ بr\%). ـ معدل الرضا التام عند المرضى كان (ع 9\%) ، وهى نسبة كبيرة مقارنة بالطرق الأخرى. الاستنتاج: طريقة إستئصـال ثنية الظفر بدون إستئصسال جذره طريقة مؤثرة جدا فى علاج الظفر

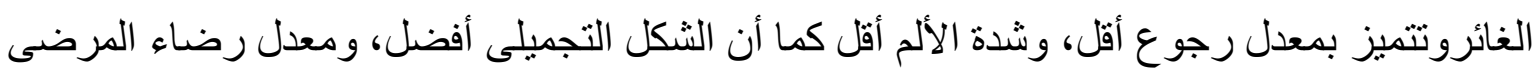

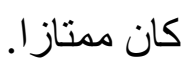

